\title{
B-cell-targeted therapies in relapsing forms of MS
}

\section{OPEN}

Divyanshu Dubey, MD

Thomas Forsthuber, MD, $\mathrm{PhD}$

Eoin P. Flanagan, MB, $\mathrm{BCh}$

Sean J. Pittock, MD

Olaf Stüve, MD, PhD

Correspondence to

Dr. Stüve:

olaf.stuve@utsouthwestern.edu

\section{ABSTRACT}

In recent years, there has been a significant increase in the therapeutic options available for the management of relapsing forms of MS. Therapies primarily targeting B cells, including therapeutic anti-CD20 monoclonal antibodies, have been evaluated in phase I, phase II, and phase III clinical trials. Results of these trials have shown their efficacy and relatively tolerable adverse effect profiles, suggesting a favorable benefit-to-risk ratio. In this review, we discuss the pathogenic role of $\mathrm{B}$ cells in MS and the rationale behind the utilization of B-cell depletion as a therapeutic cellular option. We also discuss the data of clinical trials for anti-CD20 antibodies in relapsing forms of MS and existing evidence for other B-cell-directed therapeutic strategies. Neurol Neuroimmunol Neuroinflamm 2017;4:e405; doi: 10.1212/NXI.0000000000000405

\section{GLOSSARY}

ADCC = antibody-dependent cell-mediated cytotoxicity; $\mathbf{A P R I L}=$ a proliferation-inducing ligand; $\mathbf{A P C}=$ antigen-presenting cell; $\mathbf{C D C}=$ complement-dependent cytotoxicity; $\mathbf{D C}=$ dendritic cell; $\mathbf{D M T}=$ disease-modifying therapy; $\mathbf{l g}=$ immunoglobulin; $\mathbf{O C B}=$ oligoclonal band; $\mathbf{O C B}=$ ocrelizumab; $\mathbf{O F T}=$ ofatumumab; $\mathbf{P M L}=$ progressive multifocal leukoencephalopathy; PPMS = primary progressive MS; RA = rheumatoid arthritis; $\mathbf{R T X}=$ rituximab; SLE = systemic lupus erythematosus; SPMS $=$ secondary progressive MS.

Understanding of the role of B cells in the pathogenesis of MS continues to evolve. ${ }^{1}$ The presence of oligoclonal bands (OCBs), dominant B-cell clonotypes, plasma cells and plasmablasts in the CSF, antigen-dependent affinity maturation of antibodies, immunoglobulin (Ig), and complement deposition in lesions, the presence of B-cell follicle-like structures in the meninges, and efficacy of disease-modifying therapies (DMTs) targeting B cells are all indicators of the significance of $\mathrm{B}$ cells in disease pathogenesis. ${ }^{2}$

OCBs are intrathecally produced clonally expanded antibodies. ${ }^{3,4}$ They are used in clinical practice as a very sensitive but relatively nonspecific disease biomarker, especially in the diagnosis of progressive forms of MS. The cognate antigen for these clonally expanded antibodies still remains elusive. ${ }^{5}$ Transcriptome analysis of clonally expanded B cells in CSF has shown that they are responsible for OCB production. ${ }^{4,6}$ In addition, it was shown that the transcriptomes of these B cells overlap with B cells in the MS lesions, perhaps suggesting a pathogenic contribution. B cells in MS lesions also show somatic hypermutation, implying antigen-driven expansion. ${ }^{7}$

Further evidence for the potential role of antibodies and B cells in the pathogenesis of MS is derived from the presence of Ig and complement deposition in the most prevalent subtype of demyelinating MS plaques. ${ }^{8}$ In addition, B-cell follicle-like structures have been described in the meninges of patients with primary progressive MS (PPMS). ${ }^{9}$ Of note, the IgG repertoire of extraparenchymal meningeal B-cell clones is highly similar to that of $\mathrm{B}$ cells found in brain lesion. ${ }^{10}$ 
Various cytokines and chemokines, including B-cell survival factor tumor necrosis factor superfamily $13 \mathrm{~b}$ (B-cell-activating factor [BAFF]), CXCL13, and the chemokine (C-C motif) ligand 19 (CCL19) have been identified in the CSF and lesions of patients with MS, and were proposed as key chemoattractants for other immunocompetent cells. ${ }^{11}$ The increased intrathecal Ig production and the activation of $\mathrm{B}$ cells and plasmablasts have all been associated with increased CXCL13 and CCL19 levels. In addition, increased CSF expression of CXCL13 has been associated with relapses suggesting the importance of B-cell recruitment in MS relapses and disease progression.

The $\mathrm{CD}^{+} \mathrm{T}$ helper 1 (Th1) and 17 (TH17) cell subsets have been shown to play a central role in experimental autoimmune encephalomyelitis (EAE) as well as MS pathogenesis. ${ }^{12,13}$ Activation of these cell types requires antigen presentation via MHC class II molecules, which are expressed on $\mathrm{B}$ cells as well as dendritic cells (DCs) and monocytes. ${ }^{5}$ Although DCs are considered the most effective antigen-presenting cells (APCs), B cells are specialized to serve as efficient APCs and have a unique potential to present the antigen that is available at only very low amounts because of their ability to capture a specific antigen via their $\mathrm{B}$ cell receptor. The activation of autoreactive $\mathrm{CD}^{+} \mathrm{T}$ cells occurs twice, initially in the periphery, and again later in the CNS. ${ }^{14}$ Autoreactive B cells can function as APC and activate autoreactive T cells through the trimolecular complex of $\mathrm{T}$ cell receptor/ $\mathrm{MHCII} /$ antigen and costimulatory molecules. Reciprocal activation of $\mathrm{B}$ cells by activated $\mathrm{T}$ cells via CD40L and interleukin-4 (IL-4) provides $\mathrm{B}$ cells with the capability to activate $\mathrm{T}$ cells in turn. ${ }^{15}$ Such an interplay between B cells and $\mathrm{T}$ cells results in simultaneous expansion of antigen-specific B cells and $T$ cells, which enhances proinflammatory immune response and disease progression or relapse.

$\mathrm{B}$ cells may also serve as regulatory functions, mediated, for example, via the secretion of interleukin-10. ${ }^{16}$ Studies have shown that mice containing $\mathrm{B}$ cells that cannot produce IL-10 failed to recover from EAE. ${ }^{17}$ Of interest, in an EAE model induced by myelin-oligodendrocyte peptide 35-55, naive B-cell depletion was associated with increased polarizing capacity of myeloid APCs. ${ }^{18}$ CD-20 therapy has also been shown to correlate with an increase in relative frequency and function of monocytes in treated patients. ${ }^{19}$ These findings suggest that B-cell function and contribution in CNS autoimmunity is complex, and selective inhibition of B-cell function may serve as an efficacious target for disease modification.

PLASMAPHERESIS Plasmapheresis, which is thought to remove proinflammatory Ig's and cytokines, has been used for the management of acute relapse. ${ }^{5}$ Keegan et al. ${ }^{20}$ showed that patients with type II (antibody-/complement-associated demyelination) MS lesions ${ }^{8}$ had the most favorable response to plasma exchange. None of the patients with other subtype I or III had favorable outcomes. This suggests that the efficacy of plasma exchange in the management of acute MS exacerbation may be related to its effects on B cells, Ig's, and cytokines, and specifically their downstream roles as inflammatory mediators within the CNS. ${ }^{20}$ Although it is not feasible to obtain histologic evaluations before deciding on a therapeutic intervention, certain radiologic factors such as ring-enhancing lesion or tumefactive demyelination suggestive of humoral pathogenic mechanisms may be helpful in guiding therapeutic decision making. ${ }^{21}$

ANTI-CD20 MONOCLONAL ANTIBODIES Currently, 15 DMTs are approved for patients with MS, and many more are in clinical development (table 1). ${ }^{22,23}$ Most of the approved agents target $\mathrm{B}$ cells to varying degrees. With the advent of therapeutic recombinant monoclonal antibodies (mAbs), therapeutic modalities have emerged that allow targeting of specific B-cell populations on the basis of distinct molecular targets (table 2). ${ }^{13,23,24}$ These antibodies mediate depletion of their cellular target via antibody binding and complement-dependent cytotoxicity (CDC), antibody-dependent cell-mediated cytotoxicity (ADCC), or induction of apoptosis. ${ }^{13}$

Rituximab. Rituximab (RTX) is a chimeric IgG1 Ab that binds to the CD20 cell surface epitope expressed on cells of the B-lymphocyte lineage (pre-B cells, immature B cells, mature B cells, and some memory B cells). ${ }^{13}$ It causes B-cell depletion via ADCC, CDC, and apoptosis. ${ }^{25}$ Pleuripotent stem cells, pre-B cells, and differential plasma cells do not express CD20. ${ }^{1,26}$ Therefore, B-cell reconstitution capability and humoral immunity are preserved with the use of antiCD20 mAbs. It is currently thought that B-cell depletion may eventually also reduce total antibody 
Table 1 Clinical trials for B-cell-depleting anti-CD20 monoclonal antibodies

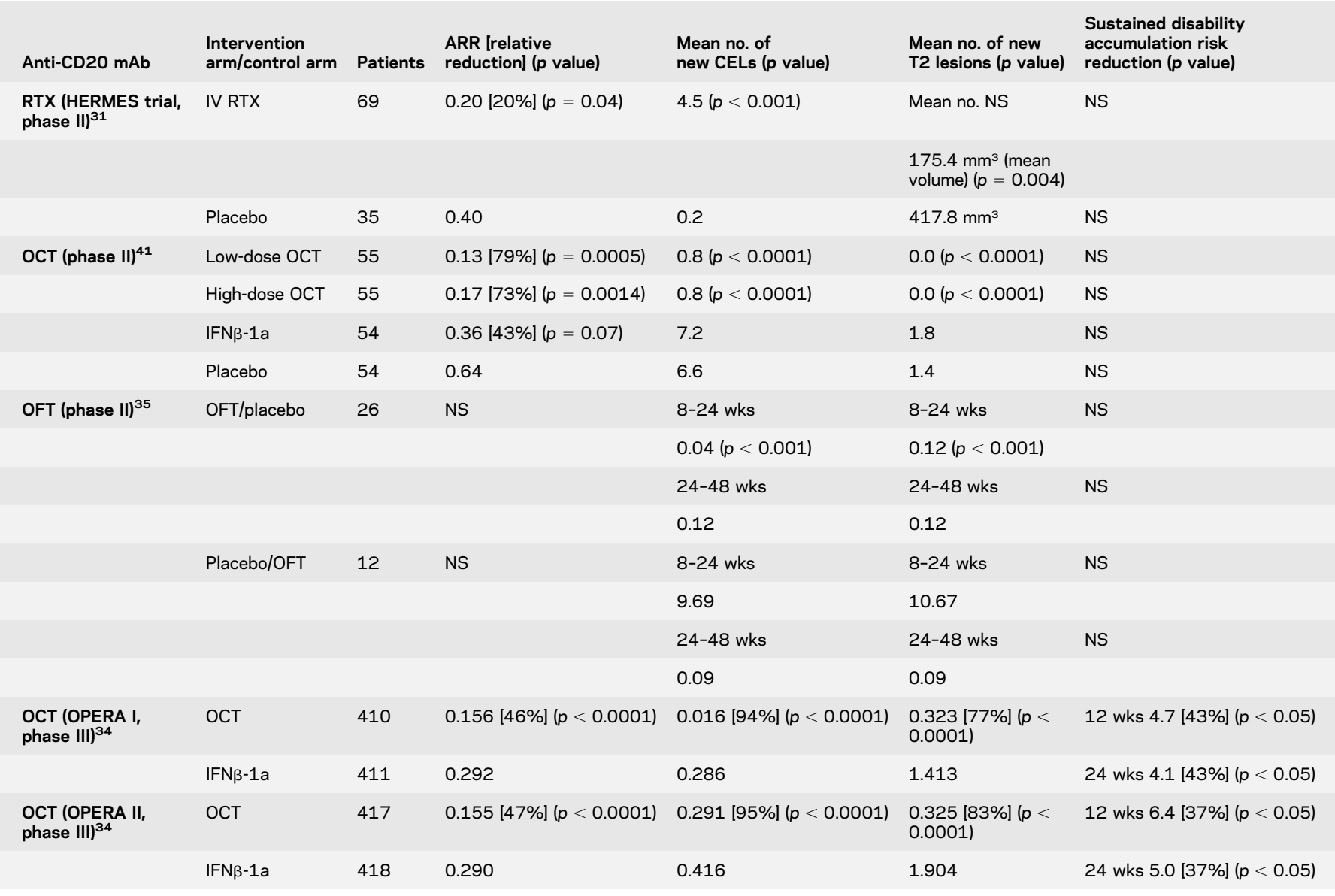

Abbreviations: $A R R=$ annualized relapse rate; $C E L=$ contrast-enhancing lesion; IFN $\beta-1 a=$ interferon $\beta 1$ - $a$; $\mathrm{mAb}=$ monoclonal antibody; $N S=$ not specified; OCT = ocrelizumab; OFT = ofatumumab.

production. However, studies have suggested that clinical effects of RTX are mainly mediated through effects on cytokine networks and T-cell activation. ${ }^{27}$ The first biosimilar monoclonal antibody, CT-P10 (Truxima), physiochemically and pharmacodynamically similar to RTX was approved by the European Medicines Agency for use in diffuse large B-cell nonHodgkin lymphoma, follicular lymphoma, chronic lymphocytic leukemia, rheumatoid arthritis (RA), granulomatosis with polyangiitis, and microscopic polyangiitis. ${ }^{28}$ Biosimilar agents provide an opportunity to lower health care cost and promote wider utilization of these therapies in developing countries. ${ }^{29}$

Clinical trials. In 2005, the index case of the use of RTX in a patient with very aggressive relapsingremitting MS was published that provided the proof of principle for the use of anti-CD20 therapy in patients with this disorder. ${ }^{30}$ In 2008 , Hauser et al. ${ }^{31}$ published the results of a phase II, double-blind, placebo-controlled trial that enrolled 104 patients with RRMS randomly assigned in 2:1 ratio to RTX (a single course administered IV 1,000 mg on days 1 and 15), or placebo. The number of new contrast- enhancing lesions (CELs) at 12, 16, 20, and 24 weeks was significantly reduced in the RTX group compared with the placebo group. At the end of 48 weeks, there was also a significant reduction in the ARR in the RTX arm (20.3\%) compared with the placebo $(40 \%)$.

Another phase II trial used RTX as an add-on therapy in RRMS patients with standard injectable DMTs. ${ }^{32}$ Thirty patients with at least 1 relapse in the previous 18 months or new CELs on previous 3 MRIs were included in the study. Patients who received RTX as an add-on therapy had a significant reduction in new CELs (74\% vs 26\%). There was also improvement in MSFC, but the EDSS remained stable.

In a large retrospective observational study, using a Swedish MS registry, 822 RTX-treated patients with MS were identified. The mean duration of follow-up was 21.8 months (SD 14.3 months). ${ }^{33}$ The majority of these patients had RRMS (557) followed by secondary progressive MS (SPMS) (198) and PPMS (67). The annualized relapse rates were $0.044,0.038$, and 0.015 in RRMS, SPMS, and PPMS, respectively. Among the patients with RRMS, 


\begin{tabular}{|c|c|c|c|c|}
\hline Drugs & Mechanism of action for B cells & Mechanism of action for $T$ cells & Adverse effects & Vaccine response \\
\hline $\begin{array}{l}\text { Interferon } \\
\text { beta }^{59}\end{array}$ & $\begin{array}{l}\text { Impaired antigen presentation; } \\
\text { increased BAFF (relative increase in } \\
\text { transitional B cells but decrease in } \\
\text { memory B cells in circulation); decreased } \\
\text { expression of costimulatory molecules } \\
\text { (CD } 40 \text { and CD } 80 \text { ); increased anti- } \\
\text { inflammatory cytokines (IL-10); and } \\
\text { inhibits proinflammatory cytokines (e.g., } \\
\text { IL-1 } \beta \text { and IL-23) }\end{array}$ & $\begin{array}{l}\text { Reduced activation of T cells } \\
\text { due to increased expression of } \\
\text { anti-inflammatory cytokines and } \\
\text { decreased expression of } \\
\text { proinflammatory cytokines }\end{array}$ & $\begin{array}{l}\text { Flu-like symptoms, transient } \\
\text { worsening of MS symptoms; } \\
\text { depression (unconfirmed), } \\
\text { anemia, thyroid dysfunction, } \\
\text { and hepatotoxicity }\end{array}$ & Unchanged \\
\hline $\begin{array}{l}\text { Glatiramer } \\
\text { acetate }^{2}\end{array}$ & $\begin{array}{l}\text { Impaired antigen presentation; } \\
\text { decreased BAFF (decreased total } \\
\text { number of circulating B cells); reduced } \\
\text { expression of costimulatory molecules } \\
\text { (CD80 and CD86); increased anti- } \\
\text { inflammatory cytokines (IL-4, IL-10, and } \\
\text { IL-13); inhibits proinflammatory } \\
\text { cytokines (e.g., TNF- } \alpha, \text { IL-17, and IL-6); } \\
\text { and decreased expression of the } \\
\text { chemokine receptor, CXCR5, and } \\
\text { elevated BDNF expression }\end{array}$ & $\begin{array}{l}\text { Reduced activation of T cells } \\
\text { due to increased expression of } \\
\text { anti-inflammatory cytokines and } \\
\text { decreased expression of } \\
\text { proinflammatory cytokines; } \\
\text { increased production of BDNF }\end{array}$ & $\begin{array}{l}\text { Injection site reaction, flushing, } \\
\text { urticaria, skin necrosis, and } \\
\text { chest pain }\end{array}$ & Impaired \\
\hline $\begin{array}{l}\text { Dimethyl } \\
\text { fumarate }^{22}\end{array}$ & $\begin{array}{l}\text { Reduced proportion of } \mathrm{CD} 27^{+} \text {memory } \\
\mathrm{B} \text { cells was decreased, but increase } \\
\text { immunoregulatory CD2 } 4^{+} \mathrm{CD} 38^{+} \\
\text {translation } 2 \text { marginal zone precursor } \\
\text { and } C D 43^{+} \mathrm{CD} 27^{+} \mathrm{B} 1 \mathrm{~B} \text { cells increase } \\
\text { IL-10 }\end{array}$ & $\begin{array}{l}\text { Increased expression of anti- } \\
\text { inflammatory cytokines and } \\
\text { reduced expression of } \\
\text { proinflammatory cytokines; } \\
\text { increased production of reduced } \\
\text { glutathione }\end{array}$ & $\begin{array}{l}\text { Abdominal pain, diarrhea, } \\
\text { nausea, vomiting, flushing, and } \\
\text { lymphopenia }\end{array}$ & Unknown \\
\hline Fingolimod $^{60}$ & $\begin{array}{l}\text { Sequesters B cells in lymphoid tissue; } \\
\text { decreased number of circulating B cells } \\
\text { and reduced entry into the CNS; } \\
\text { enhances the capacity of regulatory B } \\
\text { cells to transmigrate across the blood- } \\
\text { brain barrier; reduced expression of co- } \\
\text { stimulatory molecules (CD } 80 \text { and CD } \\
86 \text { ); increased anti-inflammatory } \\
\text { cytokines (IL-10); reduced } \\
\text { proinflammatory cytokines (e.g., TNF- } \alpha \text { ) }\end{array}$ & $\begin{array}{l}\text { Sequesters } T \text { cells in lymphoid } \\
\text { tissue }\end{array}$ & $\begin{array}{l}\text { Bradyarrhythmias, macular } \\
\text { edema, hepatic transaminitis, } \\
\text { basal cell carcinomas, varicella } \\
\text { zoster virus reactivation, and } \\
\text { herpes encephalitis }\end{array}$ & Impaired \\
\hline Teriflunomide $^{2}$ & $\begin{array}{l}\text { Potent inhibitor of dihydroorotate } \\
\text { dehydrogenase, which is needed for B- } \\
\text { cell proliferation, reduced number of } \\
\text { activated B cells, and less infiltration } \\
\text { into the CNS }\end{array}$ & $\begin{array}{l}\text { Reduces T-cell proliferation by } \\
\text { inhibition of dihydroorotate } \\
\text { dehydrogenase }\end{array}$ & $\begin{array}{l}\text { Potentially teratogenic, } \\
\text { gastrointestinal disturbances, } \\
\text { hepatotoxicity, lymphopenia, } \\
\text { thrombocytopenia, high blood } \\
\text { pressure, and opportunistic } \\
\text { infections }\end{array}$ & Marginally diminished \\
\hline Natalizumab $^{13}$ & $\begin{array}{l}\alpha-4 \text { integrin antagonist; impairs } \\
\text { transmigration into the CNS and other } \\
\text { tissues; relative decrease in naive B } \\
\text { cells, but regulatory B cells, and } \\
\text { marginal zone-like B cells increase }\end{array}$ & $\begin{array}{l}\alpha-4 \text { integrin antagonist, } \\
\text { prevents leukocyte migration, } \\
\text { induces apoptosis via } \\
\text { interaction with fibronectin }\end{array}$ & $\begin{array}{l}\text { Infusion reaction, liver disease, } \\
\text { fever, joint pain, PML, and } \\
\text { melanoma }\end{array}$ & Impaired (data unclear) \\
\hline Alemtuzumab $^{23}$ & $\begin{array}{l}\text { Increased BAFF, temporary depletion of } \\
B \text { cells via } A D C C, C D C \text {, and apoptosis } \\
\text { with subsequent reconstitution }\end{array}$ & $\begin{array}{l}\text { Long-term depletion of } T \text { cells } \\
\text { via } A D C C, C D C \text {, and apoptosis }\end{array}$ & $\begin{array}{l}\text { Infusion reaction, infections, } \\
\text { autoimmune disorders } \\
\text { (thyroiditis, ITP, and } \\
\text { glomerulonephritis) }\end{array}$ & Normal \\
\hline Daclizumab $^{13}$ & $\begin{array}{l}\text { Decreased absolute memory B-cell } \\
\text { numbers }\end{array}$ & $\begin{array}{l}\text { Depletion of activated T cells } \\
\text { via CD- } 25 \text { antagonism and } \\
\text { activation of CD56 natural killer } \\
\text { cells }\end{array}$ & $\begin{array}{l}\text { Infections, liver dysfunction, } \\
\text { skin rash, depression, and } \\
\text { malignancy }\end{array}$ & Normal \\
\hline Mitoxantrone $^{2}$ & $\begin{array}{l}\text { Potent inhibitor of type II topoisomerase } \\
\text { subsequently reduces B-cell } \\
\text { proliferation, especially CD } 27^{+} \text {memory } \\
\text { B cells; increased anti-inflammatory } \\
\text { cytokines (IL-10) }\end{array}$ & $\begin{array}{l}\text { Potent inhibitor of type II } \\
\text { topoisomerase subsequently } \\
\text { reduces T-cell proliferation, } \\
\text { inhibits activation of naive T cells } \\
\text { via inhibition of proinflammatory } \\
\text { cytokines (e.g., TNF- } \alpha \text { ) }\end{array}$ & $\begin{array}{l}\text { Congestive heart failure, acute } \\
\text { myeloid leukemia, liver } \\
\text { dysfunction, lymphopenia, and } \\
\text { potentially teratogenic, } \\
\text { discoloration of urine (purple or } \\
\text { green) }\end{array}$ & Impaired \\
\hline $\begin{array}{l}\text { Anti-CD20 mAb } \\
\text { (RTX, OFT, and } \\
\text { ocrelizumab) }^{13}\end{array}$ & $\begin{array}{l}\text { Depletion of B cells in circulation and } \\
\text { CNS via ADCC and/or CDC and } \\
\text { increased anti-inflammatory cytokines } \\
\text { (IL-10) }\end{array}$ & $\begin{array}{l}\text { Reduced activation of naive T } \\
\text { cells via reduction of antigen- } \\
\text { presenting cells and inhibition of } \\
\text { proinflammatory cytokines (GM- } \\
\text { CSF) }\end{array}$ & $\begin{array}{l}\text { Infusion reaction, infections, } \\
\text { PML }\end{array}$ & Impaired \\
\hline
\end{tabular}

Abbreviations: $A D C C=$ antibody-dependent cell-mediated cytotoxicity; BAFF = B-cell-activating factor of the tumor necrosis factor family; $C D C=$ complement-dependent cytotoxicity; GM-CSF = granulocyte-macrophage colony-stimulating factor; IL = interleukin; ITP = immune thrombocytopenic purpura; OFT = ofatumumab; PML = progressive multifocal leukoencephalopathy; RTX = rituximab; TNF- $\alpha=$ tumor necrosis factor $\alpha$.

the median EDSS remained unchanged over the period of follow-up, but it increased by 0.5 and 1.0 in SPMS and PPMS, respectively.
Because of the chimeric nature of RTX, 24.6\% of patients developed anti-idiotypic antibodies in the HERMES trial. ${ }^{31}$ No clear impact of these antibodies 
on efficacy or rate adverse effects has been proven. However, humanized or human anti-CD20 antibodies have much lower immunogenicity or rate of antiidiotypic antibody formation. ${ }^{34,35}$

Safety. Infusion-associated reactions are the most common adverse effect of RTX. ${ }^{13,31,32}$ The majority of patients (78\%) who received RTX in the HERMES trial had infusion-associated reactions compared with $40 \%$ in the placebo group. Most of these reactions were mild to moderate in severity $(92.6 \%) .{ }^{31}$ The administration of glucocorticoids and antihistaminic agents before the infusion and slowing down the rate of infusion may reduce the occurrence or severity of infusion-associated reactions. ${ }^{13,31}$ Other potential adverse effects commonly reported in the studies included headache, sinusitis, nausea, upper respiratory tract infections, and urinary tract infections. Malignant thyroid neoplasm was also diagnosed in one patient. ${ }^{31,32,36}$ In addition, in the Swedish MS registry study, 3 malignancies were detected, 2 basilomas and 1 pyoderma gangrenosum. ${ }^{33}$

The rate of infection following RTX administration has been reported as 18.1 per 100 patientyears. In one study that evaluated the efficacy and safety of RTX in different autoimmune diseases, 7 of 11 deaths were attributed to underlying infections. ${ }^{37}$ There have been few cases of progressive multifocal leukoencephalopathy (PML) reported following administration of RTX in combination with other immunosuppressive agents in patients with lymphoproliferative disorders, RA, systemic lupus erythematosus (SLE), and autoimmune thrombocytopenia, but until now, no cases have been reported in patients with MS in clinical trial or with off-label usage. ${ }^{38}$ It remains unclear whether there is a causal relationship between anti-CD20 treatment and development of PML or the underlying immunocompromised state (lymphoproliferative disorder) and cotreatment with other immunosuppressive medications contributed to development of this life-threatening infection. Among patients switched from natalizumab to either fingolimod or RTX due to John Cunningham virus seropositivity, RTX had better efficacy in reducing relapses as well as lowering adverse event rate. ${ }^{39}$ Therefore, clinicians may have a preference to use anti-CD20 therapy in JC virus-seropositive patients. Because of rheumatology and oncology data on incidence of PML among RTX-treated individuals, CSF evaluation for JC virus infection should be considered before initiating antiCD20 treatment.

Ocrelizumab. Ocrelizumab (OCR) also targets and depletes $\mathrm{CD}^{+}{ }^{+} \mathrm{B}$ cells. Compared with RTX, OCR is a humanized IgG1 mAb, and it is less immunogenic. ${ }^{40}$ Therefore, it leads to fewer allergic reactions and development of anti-idiotypic antibodies. ${ }^{40,41}$
It targets different but overlapping epitope than RTX with higher avidity. Its efficacy is mediated more by ADCC than by CDC. ${ }^{13,40}$ It induces rapid B-cell depletion following infusion; recovery of $\mathrm{B}$ cell occurs at 3 months. ${ }^{42}$ Given the lower immunogenicity and higher avidity for the epitope, OCR might have a more favorable risk-benefit profile than RTX.

Clinical trials. A phase II, randomized, doubleblind, placebo-controlled trial comparing OCR with placebo and IFN $\beta$-1a was published in $2011 .{ }^{41} \mathrm{In}$ this multicenter study (79 centers and 20 countries), patients were randomized 1:1:1:1 to receive placebo, low-dose OCR (600 mg), high-dose OCR (2,000 $\mathrm{mg}$ ), or IFN $\beta$-1a (open-label, rater-blinded exploratory arm). After completion of the initial 24 weeks, patients in the placebo and IFN $\beta$ - 1 a were switched to receive OCR. There was a significant reduction in the number of CELs; $89 \%$ and $96 \%$ in the low- and high-dose OCR treatment arms, respectively, compared with the placebo. The proportion of individuals free from new CELs was also significantly lower in the OCR groups compared with the placebo group (lowdose OCR: 77\%, high-dose OCR: $82.7 \%$, and placebo: 35\%). The ARR in the placebo, low-dose OCR, high-dose OCR, and IFN $\beta$-1a groups was 30\%, 5\%, $7 \%$, and $17 \%$, respectively. The ARR was significantly lower in both the high-dose (7\%) and low-dose (5\%) OCR groups compared with the placebo (30\%). There was a significant difference in the ARR between lowdose OCR (5\%) and IFNß-1a (17\%), but not between high-dose OCR and IFN $\beta$-1a.

Two phase III trials (OPERA I and II) with an identical design were recently published. ${ }^{34}$ These were multicenter, randomized, double-blind, double-dummy, parallel-group trials to evaluate the efficacy and safety of OCR compared with IFN $\beta-1 \mathrm{a}$ in patients with RRMS. In 2 trials enrolled (OPERA I: 821 and OPERA II: 835), patients were aged between 18 and 55 years, with a diagnosis of RRMS according to the 2010 revised McDonald criteria, ${ }^{43}$ EDSS score $<5.5$ at screening, and at least 2 documented clinical attacks within the 2 years prior or 1 within 1 year before screening. Patients were randomized $1: 1$ to receive OCR (300 mg or $600 \mathrm{mg}$ ) intravenously every 24 weeks or IFN $\beta$-1a $44 \mu \mathrm{g}$ subcutaneously 3 times per week throughout a 96week treatment period. EDSS raters were masked to the clinical and laboratory data, which could have been suggestive of either OCR or IFN $\beta$-1a group. In both studies, OPERA I and II, there was a significant reduction of ARR in the OCR treatment arms compared with IFN $\beta-1$ a $46 \%$ and $47 \%$, respectively. There was also a significant reduction in confirmed disability progression at 12 (OPERA I 43\% and OPERA II 37\%) and 24 weeks (OPERA I 43\% and OPERA II 37\%) compared with IFN $\beta-1$ a. The 
mean relative reduction in CELs with OCR treatment compared with IFN $\beta$-1a treatment at weeks 24, 48, and 96 was $94 \%$ and $95 \%$ in OPERA I and OPERA II, respectively. The number of new and/or enlarging T2 hyperintense lesions was also significantly reduced in the OCR-treated patients compared with IFN $\beta$-1a treatment: $77 \%$ in OPERA I and $83 \%$ in OPERA II. Relatively no evidence of disease activity, ${ }^{44}$ defined as the absence of protocoldefined relapses, confirmed disability progression events, new or enlarging T2 lesions, and CELs from baseline to week 96, improvement of OCR treatment arms compared with INF $\beta$-1a treatment arms in OPERA I (77\%) and OPERA II (89\%) was significantly higher. In both these studies, OCR treatment was also associated with the relative reduction in rates of brain volume loss compared with IFN $\beta-1 \mathrm{a}, 23.5 \%$ and $23.8 \%$ in OPERA I and OPERA II, respectively.

Safety. The most common adverse effects reported in the phase II studies included headache, infections, and infusion-associated events. There was 1 reported death in the high-dose OCR group due to systemic inflammatory response syndrome.

In the phase III studies, a higher proportion of OCR-treated patients (34.3\%) developed infusionrelated reaction compared with IFN $\beta$-1a-treated patients $(9.7 \%)$. Because of infusion-related reactions during the first infusion, $1.3 \%$ of study participants withdrew from OCR treatment. The rates of infections between the OCR treatment arms and IFN $\beta$-1a arms were comparable, $58.4 \%$ and $52.4 \%$, respectively. The most commonly reported and diagnosed infections were upper respiratory tract infections, nasopharyngitis, and urinary tract infections. Headache, back pain, joint pain, and psychiatric disorders were other common adverse effects. There was no significant difference in serious adverse effects reported (OCR treatment arm $6.9 \%$ vs IFN $\beta-1$ a treatment arm $8.7 \%)$. Four malignancies were reported in the OCR arm, which does not prove a causal relationship: renal cell cancer (1), melanoma (1), and breast cancer (2); whereas 2 patients in the INF $\beta$-1a arm were reported to have malignancies, squamous cell carcinoma (1), and mantle cell lymphoma (1). The number of malignancies was higher $(11,2.3 \%)$ in the study evaluating OCR for patients with progressive MS. ${ }^{45}$ Three deaths were reported during OPERA trials, 2 in an IFN $\beta$-1a arm (1 suicide and 1 mechanical ileus) and 1 in an OCR arm (suicide). ${ }^{24} \mathrm{~A}$ total of 1246 patients have been recruited in the OPERA open-label extension study to evaluate the long-term safety, tolerability, and efficacy of OCR. These patients are on a regimen of $600 \mathrm{mg}$ OCR every 24 weeks.

Ofatumumab. Ofatumumab (OFT) is a fully human IgG1 mAb targeting $\mathrm{CD}_{20}{ }^{+} \mathrm{B}$ cells. ${ }^{13,46}$ OFT mediates B-cell depletion via CDC and ADCC. ${ }^{35}$ OFT binds to a novel membrane-proximal epitope. The rate at which it dissociates from the epitope is slower than RTX, which results in improved CDC. ${ }^{46,47}$ As expected, OFT is less immunogenic than RTX. ${ }^{48}$

Clinical trials. In 2014, a phase II, placebocontrolled, double-blind trial was published in which patients were randomized to receive either OFT or placebo infusions at 2-week intervals. ${ }^{35}$ At 24 weeks, the treatment arms were switched so that patients receiving OFT were given placebo and vice versa. Thirty-eight patients were randomized to either OFT first and placebo later $(n=26)$ or placebo first and OFT later $(\mathrm{n}=12)$ groups. The number of new CELs during 8-24 weeks and the total CELs in the OFT group were significantly reduced. The percentage reduction in the number of T1 CELs from 8 to 24 weeks was $>99 \%$. During the first 24 weeks, in the OFT arm, $19 \%$ of patients had a clinical relapse, whereas in the placebo arm, $25 \%$ of patients had a relapse. After the therapies were switched at 24 weeks, 1 patient who had initially been on OFT relapsed, but none of the patients switched from placebo to OFT developed relapses. No clinical significant difference in EDSS or MSFC scores were observed in the OFT arm compared with the placebo or compared with the baseline.

Safety. The most prevalent adverse effect was an infusion-related reaction on the first day of infusion more commonly found in the OFT treatment group compared with the placebo. One patient receiving OFT discontinued treatment because of development on pharyngeal edema, pruritus, and nasal congestion during the first infusion. It is important that none of the patients on OFT tested for human anti-chimeric antibody were seropositive at the end of 48 weeks, pointing toward lower immunogenicity of OFT compared with RTX.

OTHER B-CELL-TARGETING THERAPIES The CD19 molecule is expressed on B cells that express CD20, and also on some antibody-producing plasmablasts, which makes it another potential therapeutic target for patients with RRMS. One therapeutic agent in development that targets CD19 is inebilizumab (MEDI-551), a humanized recombinant mAb. ${ }^{26} \mathrm{It}$ has been evaluated in a phase I trial for patients with relapsing forms of MS (NCT01585766). The study is completed, but no study results are available. Of importance, inebilizumab has demonstrated equal or better efficacy in depletion of human primary B cells in autologous ADCC assays, as well as longer-lasting $\mathrm{B}$-cell depletion compared with RTX. ${ }^{1,26}$

Epratuzumab is a monoclonal antibody targeting CD22, a B-cell transmembrane glycoprotein mostly 
expressed on mature B cells that act as an accessorysignaling component of the B-cell antigen receptor. Epratuzumab has been evaluated in patients with SLE and non-Hodgkin lymphoma, ${ }^{49}$ but no studies are currently under way in MS.

The BAFF receptor, which promotes cell survival through various developmental stages of B cells, is another therapeutic target of interest. ${ }^{11}$ It is present on B-cell subsets in secondary lymphoid organs, as well as on a small subset of $\mathrm{T}$ cells. ${ }^{11,50}$ Of interest, a study testing a recombinant fusion protein neutralizing BAFF and a proliferation-inducing ligand (APRIL), another B-cell stimulator showed an increased inflammatory activity in patients with MS. ${ }^{51}$ Reasons for these counterintuitive results are unclear, but it could be secondary to the effect of antiBAFF/APRIL (Atacicept) on CD27-negative naive B cells while having a little effect on memory B cells. ${ }^{52}$

Tabalumab, a human IgG4 mAb that targets and neutralizes both soluble and membrane-bound BAFF, ${ }^{53}$ was evaluated in a phase II clinical trial (NCT00882999). The trial was initiated in April 2009, but subsequently canceled in 2011. Whether the termination was due to safety issues, inefficacy, increased disease activity, or other reasons remains unknown.

Another human IgG1 mAb targeting receptor for BAFF (VAY736) was evaluated in a phase II trial for patients with RRMS. ${ }^{1}$ VAY736 is hypothesized to cause B cell and serum Ig depletion. The study was completed, but no details or results are available thus far.

Tocilizumab is a humanized monoclonal IgG1 antibody targeting the IL-6 receptor and is FDA approved for the management of RA, polyarticular juvenile idiopathic arthritis, and active systemic juvenile idiopathic arthritis. ${ }^{54}$ IL-6 drives the differentiation of B-cell subsets, including plasmablasts. ${ }^{55}$ This mAb has also shown potential efficacy in the management of patients with neuromyelitis optica disorder refractory to RTX. It is another potential therapeutic option that may be evaluated in patients with MS in the near future.

Bortezomib, a proteasome inhibitor which preferentially affects plasma cell differentiation and survival, and predisposes them to apoptotic cell death, has been used in the management of multiple myeloma. ${ }^{56,57}$ Patients with refractory NMDA receptor encephalitis have also shown a favorable response, suggesting its utility in disorders with cell-mediated and antibody-mediated mechanisms. ${ }^{58}$ Currently, there are no data on the use of bortezomib for MS, but in the future, these agents might prove to be useful for the management of refractory cases.

CONCLUSIONS Recently published data from OCR phase III trials further lend support to efficacy and safety of B-cell-depleting therapies in RRMS and have resulted in the first approved B-cell-specific therapy for MS. ${ }^{34}$ Agents that target other B-cellassociated molecules are also currently in clinical development. ${ }^{1,13}$ These trials aim to target B-cell subsets more specifically or more cell subsets of the Bcell lineage.

Some failed study initiatives illustrate the heterogeneous role of B-cell subsets. A better understanding of the biology of disease stage-specific and compartment-specific B-cell subsets will be required to further improve B-cell-targeted therapies.

\section{AUTHOR CONTRIBUTIONS}

Divyanshu Dubey: drafting/revising the manuscript, study concept or design, and analysis or interpretation of data. Thomas Forsthuber: drafting/revising the manuscript. Eoin P. Flanagan: drafting/revising the manuscript and analysis or interpretation of data. Sean J. Pittock: drafting/revising the manuscript. Olaf Stüve: drafting/revising the manuscript, study concept or design, analysis or interpretation of data, and study supervision.

\section{STUDY FUNDING}

No targeted funding reported.

\section{DISCLOSURE}

D. Dubey reports no disclosures. T. Forsthuber has served on the editorial boards of Clinical Immunology, Journal of Immunology, PLoS One, and Frontiers in Multiple Sclerosis and Neuroimmunology and Immunotherapy and has received research support from the National MS Society. E.P. Flanagan reports no disclosures. S.J. Pittock is a named inventor on patents that relate to functional AQP4/NMO-IgG assays and $\mathrm{NMO}-\mathrm{IgG}$ as a cancer marker; receives research support from Alexion Pharmaceuticals, Inc., MedImmune, Grifols, the Guthy-Jackson Charitable Foundation, and the NIH; and has provided consultation to Alexion Pharmaceuticals, MedImmune LLC, and Chugai Pharmaceutical, but has received no personal fees or personal compensation for these consulting activities; all compensation for consulting activities is paid directly to Mayo Clinic. O. Stüve serves on the editorial boards of JAMA Neurology, Multiple Sclerosis Journal, and Therapeutic Advances in Neurologic Disorders; receives grant support from Teva Pharmaceuticals and Opexa Therapeutics; funded by a Merit Review grant from the US Department of Veterans Affairs, Biomedical Laboratory Research and Development; served on data monitoring committees for Pfizer, Novartis, and TG Therapeutics; collaborated with Medscape on educational initiatives; represented Novartis in front of a Scientific Advisory Group at the European Medicines Agency (EMA); advised Genentech and Sanofi-Aventis; participated in a Teva-sponsored meeting; consulted for Navigant Consulting; and received travel support from Pfizer. Go to Neurology.org/nn for full disclosure forms.

Received May 11, 2017. Accepted in final form July 13, 2017.

\section{REFERENCES}

1. Gasperi C, Stuve O, Hemmer B. B cell-directed therapies in multiple sclerosis. Neurodegener Dis Manag 2016;6: $37-47$.

2. Milo R. Therapeutic strategies targeting B-cells in multiple sclerosis. Autoimmun Rev 2016;15:714-718.

3. Kabat EA, Moore DH, Landow H. An electrophoretic study of the protein components in cerebrospinal fluid and their relationship to the serum proteins. J Clin Invest 1942;21:571-577.

4. Obermeier B, Mentele R, Malotka J, et al. Matching of oligoclonal immunoglobulin transcriptomes and proteomes of cerebrospinal fluid in multiple sclerosis. Nat Med 2008; 14:688-693. 
5. Lehmann-Horn K, Kronsbein HC, Weber MS. Targeting $\mathrm{B}$ cells in the treatment of multiple sclerosis: recent advances and remaining challenges. Ther Adv Neurol Disord 2013;6:161-173.

6. Obermeier B, Lovato L, Mentele R, et al. Related B cell clones that populate the CSF and CNS of patients with multiple sclerosis produce CSF immunoglobulin. J Neuroimmunol 2011;233:245-248.

7. Qin Y, Duquette P, Zhang Y, Talbot P, Poole R, Antel J. Clonal expansion and somatic hypermutation of $\mathrm{V}(\mathrm{H})$ genes of B cells from cerebrospinal fluid in multiple sclerosis. J Clin Invest 1998;102:1045-1050.

8. Lucchinetti C, Bruck W, Parisi J, Scheithauer B, Rodriguez M, Lassmann H. Heterogeneity of multiple sclerosis lesions: implications for the pathogenesis of demyelination. Ann Neurol 2000;47:707-717.

9. Magliozzi R, Howell O, Vora A, et al. Meningeal B-cell follicles in secondary progressive multiple sclerosis associate with early onset of disease and severe cortical pathology. Brain 2007;130:1089-1104.

10. Lovato L, Willis SN, Rodig SJ, et al. Related B cell clones populate the meninges and parenchyma of patients with multiple sclerosis. Brain 2011;134:534-541.

11. Rodig SJ, Shahsafaei A, Li B, Mackay CR, Dorfman DM. BAFF-R, the major B cell-activating factor receptor, is expressed on most mature B cells and B-cell lymphoproliferative disorders. Hum Pathol 2005;36:1113-1119.

12. Weber MS, Hemmer B, Cepok S. The role of antibodies in multiple sclerosis. Biochim Biophys Acta 2011;1812: 239-245.

13. Dubey D, Kieseier BC, Hartung HP, Hemmer B, MillerLittle WA, Stuve O. Clinical management of multiple sclerosis and neuromyelitis optica with therapeutic monoclonal antibodies: approved therapies and emerging candidates. Expert Rev Clin Immunol 2015;11:93-108.

14. Probstel AK, Sanderson NS, Derfuss T. B cells and autoantibodies in multiple sclerosis. Int J Mol Sci 2015;16: 16576-16592.

15. Harp CT, Lovett-Racke AE, Racke MK, Frohman EM, Monson NL. Impact of myelin-specific antigen presenting $\mathrm{B}$ cells on $\mathrm{T}$ cell activation in multiple sclerosis. Clin Immunol 2008;128:382-391.

16. Fillatreau S, Sweenie CH, McGeachy MJ, Gray D, Anderton SM. B cells regulate autoimmunity by provision of IL-10. Nat Immunol 2002;3:944-950.

17. Wolf SD, Dittel BN, Hardardottir F, Janeway CA Jr. Experimental autoimmune encephalomyelitis induction in genetically B cell-deficient mice. J Exp Med 1996; 184:2271-2278.

18. Weber MS, Prod'homme T, Patarroyo JC, et al. B-cell activation influences $\mathrm{T}$-cell polarization and outcome of anti-CD20 B-cell depletion in central nervous system autoimmunity. Ann Neurol 2010;68:369-383.

19. Lehmann-Horn K, Schleich E, Hertzenberg D, et al. AntiCD20 B-cell depletion enhances monocyte reactivity in neuroimmunological disorders. J Neuroinflammation 2011;8:146

20. Keegan M, Konig F, McClelland R, et al. Relation between humoral pathological changes in multiple sclerosis and response to therapeutic plasma exchange. Lancet 2005;366:579-582.

21. Magana SM, Keegan BM, Weinshenker BG, et al. Beneficial plasma exchange response in central nervous system inflammatory demyelination. Arch Neurol 2011;68:870-878.
22. Dubey D, Kieseier BC, Hartung HP, et al. Dimethyl fumarate in relapsing-remitting multiple sclerosis: rationale, mechanisms of action, pharmacokinetics, efficacy and safety. Expert Rev Neurother 2015;15:339-346.

23. Dubey D, Cano CA, Stuve O. Intractable and highly active relapsing multiple sclerosis—role of alemtuzumab. Neuropsychiatr Dis Treat 2015;11:2405-2414.

24. Menge T, Dubey D, Warnke C, Hartung HP, Stuve O. Ocrelizumab for the treatment of relapsing-remitting multiple sclerosis. Expert Rev Neurother 2016;16:1131-1139.

25. Grillo-Lopez AJ. Rituximab: an insider's historical perspective. Semin Oncol 2000;27:9-16.

26. Chen D, Gallagher S, Monson NL, Herbst R, Wang Y. Inebilizumab, a B cell-depleting anti-CD19 antibody for the treatment of autoimmune neurological diseases: insights from preclinical studies. J Clin Med 2016;5:E107.

27. Reff ME, Carner K, Chambers KS, et al. Depletion of B cells in vivo by a chimeric mouse human monoclonal antibody to CD20. Blood 1994;83:435-445.

28. Deeks ED. CT-P10 (truxima): a rituximab biosimilar. BioDrugs 2017;31:275-278.

29. Vital EM, Kay J, Emery P. Rituximab biosimilars. Expert Opin Biol Ther 2013;13:1049-1062.

30. Stuve O, Cepok S, Elias B, et al. Clinical stabilization and effective B-lymphocyte depletion in the cerebrospinal fluid and peripheral blood of a patient with fulminant relapsingremitting multiple sclerosis. Arch Neurol 2005;62:1620-1623.

31. Hauser SL, Waubant E, Arnold DL, et al. B-cell depletion with rituximab in relapsing-remitting multiple sclerosis. $\mathrm{N}$ Engl J Med 2008;358:676-688.

32. Naismith RT, Piccio L, Lyons JA, et al. Rituximab add-on therapy for breakthrough relapsing multiple sclerosis: a 52 week phase II trial. Neurology 2010;74:1860-1867.

33. Salzer J, Svenningsson R, Alping P, et al. Rituximab in multiple sclerosis: a retrospective observational study on safety and efficacy. Neurology 2016;87:2074-2081.

34. Hauser SL, Bar-Or A, Comi G, et al. Ocrelizumab versus interferon beta-1a in relapsing multiple sclerosis. $\mathrm{N}$ Engl J Med 2017;376:221-234.

35. Sorensen PS, Lisby S, Grove R, et al. Safety and efficacy of ofatumumab in relapsing-remitting multiple sclerosis: a phase 2 study. Neurology 2014;82:573-581.

36. Hawker K, O'Connor P, Freedman MS, et al. Rituximab in patients with primary progressive multiple sclerosis: results of a randomized double-blind placebo-controlled multicenter trial. Ann Neurol 2009;66:460-471.

37. Tony HP, Burmester G, Schulze-Koops H, et al. Safety and clinical outcomes of rituximab therapy in patients with different autoimmune diseases: experience from a national registry (GRAID). Arthritis Res Ther 2011; 13:R75.

38. Palazzo E, Yahia SA. Progressive multifocal leukoencephalopathy in autoimmune diseases. Joint Bone Spine 2012;79: 351-355.

39. Alping P, Frisell T, Novakova L, et al. Rituximab versus fingolimod after natalizumab in multiple sclerosis patients. Ann Neurol 2016;79:950-958.

40. Kausar F, Mustafa K, Sweis G, et al. Ocrelizumab: a step forward in the evolution of B-cell therapy. Expert Opin Biol Ther 2009;9:889-895.

41. Kappos L, Li D, Calabresi PA, et al. Ocrelizumab in relapsing-remitting multiple sclerosis: a phase 2 , randomised, placebo-controlled, multicentre trial. Lancet 2011;378:1779-1787. 
42. Sorensen PS, Blinkenberg M. The potential role for ocrelizumab in the treatment of multiple sclerosis: current evidence and future prospects. Ther Adv Neurol Disord 2016;9:44-52.

43. Polman CH, Reingold SC, Banwell B, et al. Diagnostic criteria for multiple sclerosis: 2010 revisions to the McDonald criteria. Ann Neurol 2011;69:292-302.

44. Bevan CJ, Cree BA. Disease activity free status: a new end point for a new era in multiple sclerosis clinical research? JAMA Neurol 2014;71:269-270.

45. Montalban X, Hauser SL, Kappos L, et al. Ocrelizumab versus placebo in primary progressive multiple sclerosis. $\mathrm{N}$ Engl J Med 2017;376:209-220.

46. Zhang B. Ofatumumab. MAbs 2009;1:326-331.

47. Rommer PS, Patejdl R, Winkelmann A, Benecke R, Zettl UK. Rituximab for secondary progressive multiple sclerosis: a case series. CNS Drugs 2011;25:607-613.

48. Sorensen PS. New management algorithms in multiple sclerosis. Curr Opin Neurol 2014;27:246-259.

49. Morschhauser F, Kraeber-Bodere F, Wegener WA, et al. High rates of durable responses with anti-CD22 fractionated radioimmunotherapy: results of a multicenter, phase I/II study in non-Hodgkin's lymphoma. J Clin Oncol 2010;28:3709-3716.

50. Hartung HP, Kieseier BC. Atacicept: targeting B cells in multiple sclerosis. Ther Adv Neurol Disord 2010;3: 205-216.

51. Kappos L, Hartung HP, Freedman MS, et al. Atacicept in multiple sclerosis (ATAMS): a randomised, placebocontrolled, double-blind, phase 2 trial. Lancet Neurol 2014;13:353-363.

52. Genovese MC, Kinnman N, de La Bourdonnaye G, Pena Rossi C, Tak PP. Atacicept in patients with rheumatoid arthritis and an inadequate response to tumor necrosis factor antagonist therapy: results of a phase II, randomized, placebo-controlled, dose-finding trial. Arthritis Rheum 2011; 63:1793-1803.

53. Isenberg DA, Petri M, Kalunian K, et al. Efficacy and safety of subcutaneous tabalumab in patients with systemic lupus erythematosus: results from ILLUMINATE-1, a 52-week, phase III, multicentre, randomised, double-blind, placebocontrolled study. Ann Rheum Dis 2016;75:323-331.

54. Ringelstein M, Ayzenberg I, Harmel J, et al. Long-term therapy with interleukin 6 receptor blockade in highly active neuromyelitis optica spectrum disorder. JAMA Neurol 2015;72:756-763.

55. Jego G, Bataille R, Pellat-Deceunynck C. Interleukin-6 is a growth factor for nonmalignant human plasmablasts. Blood 2001;97:1817-1822.

56. Behrendt V, Krogias C, Reinacher-Schick A, Gold R, Kleiter I. Bortezomib treatment for patients with anti-Nmethyl-d-aspartate receptor encephalitis. JAMA Neurol 2016;73:1251-1253.

57. Mohty M, Malard F, Mohty B, Savani B, Moreau P, Terpos E. The effects of bortezomib on bone disease in patients with multiple myeloma. Cancer 2014;120: 618-623.

58. Scheibe F, Pruss H, Mengel AM, et al. Bortezomib for treatment of therapy-refractory anti-NMDA receptor encephalitis. Neurology 2017;88:366-370.

59. Stuve O, Chabot S, Jung SS, Williams G, Yong VW. Chemokine-enhanced migration of human peripheral blood mononuclear cells is antagonized by interferon beta-1b through an effect on matrix metalloproteinase-9. J Neuroimmunol 1997;80:38-46.

60. Miyazaki Y, Niino M, Fukazawa T, et al. Suppressed proinflammatory properties of circulating $B$ cells in patients with multiple sclerosis treated with fingolimod, based on altered proportions of B-cell subpopulations. Clin Immunol 2014;151:127-135. 


\title{
Neurology $^{\odot}$ \\ Neuroimmunology \& Neuroinflammation
}

\author{
B-cell-targeted therapies in relapsing forms of MS
}

Divyanshu Dubey, Thomas Forsthuber, Eoin P. Flanagan, et al.

Neurol Neuroimmunol Neuroinflamm 2017;4;

DOI 10.1212/NXI.0000000000000405

This information is current as of October 23, 2017

\section{Updated Information \& Services}

References

Subspecialty Collections

Permissions \& Licensing

Reprints including high resolution figures, can be found at:

http://nn.neurology.org/content/4/6/e405.full.html

This article cites 60 articles, 5 of which you can access for free at: http://nn.neurology.org/content/4/6/e405.full.html\#\#ref-list-1

This article, along with others on similar topics, appears in the following collection(s):

All Demyelinating disease (CNS)

http://nn.neurology.org//cgi/collection/all_demyelinating_disease_cns

All Immunology

http://nn.neurology.org//cgi/collection/all_immunology

Autoimmune diseases

http://nn.neurology.org//cgi/collection/autoimmune_diseases

Multiple sclerosis

http://nn.neurology.org//cgi/collection/multiple_sclerosis

Optic neuritis; see Neuro-ophthalmology/Optic Nerve

http://nn.neurology.org//cgi/collection/optic_neuritis

Information about reproducing this article in parts (figures,tables) or in its entirety can be found online at:

http://nn.neurology.org/misc/about.xhtml\#permissions

Information about ordering reprints can be found online:

http://nn.neurology.org/misc/addir.xhtml\#reprintsus

Neurol Neuroimmunol Neuroinflamm is an official journal of the American Academy of Neurology.

Published since April 2014, it is an open-access, online-only, continuous publication journal. Copyright

Copyright (C) 2017 The Author(s). Published by Wolters Kluwer Health, Inc. on behalf of the American

Academy of Neurology.. All rights reserved. Online ISSN: 2332-7812.

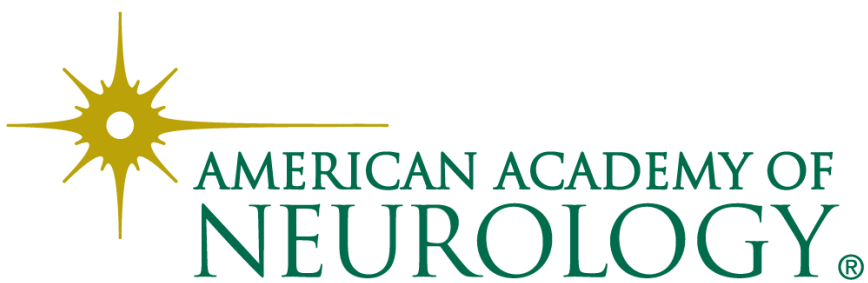

